\title{
Intertidal macrozoobenthos in sandy beaches of Bahía Nueva (Patagonia, Argentina) and their use as bioindicators of environmental impact
}

\author{
AGUSTINA FERRANDO ${ }^{1}$, JOSÉ LUIS ESTEVES ${ }^{2}$, RODOLFO ELÍAS ${ }^{3}$ \\ and NURIA MÉNDEZ ${ }^{1}$ \\ ${ }^{1}$ Unidad Académica Mazatlán, Instituto de Ciencias del Mar y Limnología, Universidad Nacional Autónoma de México, \\ Av. Joel Montes Camarena s/n, Mazatlán 82040, Sinaloa, México. E-mail: agustina@ola.icmyl.unam.mx \\ ${ }^{2}$ Centro Nacional Patagónico (CENPAT-CONICET), Bv. Brown 3.000, Puerto Madryn 9120, Chubut, Argentina. \\ ${ }^{3}$ Universidad Nacional de Mar del Plata, Dean Funes 3350, B 7602 AYL Mar del Plata, Buenos Aires, Argentina.
}

\begin{abstract}
SUMMARY: Macrozoobenthos were collected from urban sandy beaches of Puerto Madryn and adjacent areas in November 2005. Multivariate analysis techniques (ANOVA, nMDS, ANOSIM, SIMPER and RDA) were used to characterize the area based on the relationships among biological and environmental variables. The areas affected by outfall of fishery factories and pluvial effluent were defined as "perturbed zones" due to the dominance of the pollution indicator polychaetes Boccardia polybranchia and Capitella "capitata" sp., which are associated with high values of ammonium, phosphates and organic matter. However, sandy beaches located $15 \mathrm{~km}$ from the city were considered as "unperturbed zones" because Psammodrilidae and Puelche orensanzi dominated, and they had high values of nitrates and dissolved oxygen. These taxa seem to be good candidates as indicators of clean zones for further studies. This is the first record of the family Psammodrilidae in the South Atlantic.
\end{abstract}

Keywords: Polychaeta, anthropogenic influence, macrobenthic community, Capitella "capitata" sp., Boccardia polybranchia, Psammodrilidae, sandy beaches.

\begin{abstract}
RESUMEN: Macrozoobentos intermareal en playas arenosas de la Bahía Nueva (Patagonia, Argentina) y su USO COMO BIOINDICADORES DE IMPACTO AMBIENTAL. - Se recolectaron muestras de macrozoobentos en playas arenosas de la ciudad de Puerto Madryn y áreas adyacentes, en noviembre de 2005. Los análisis multivariantes (ANOVA, nMDS, ANOSIM, SIMPER y RDA) permitieron caracterizar el área en base a la relación entre las variables biológicas y ambientales. Las áreas afectadas por los desagües procedentes de las fábricas de pescado y los pluviales, fueron definidas como "zonas perturbadas", debido a la dominancia de los poliquetos indicadores de contaminación Boccardia polybranchia y Capitella "capitata" sp., asociados a altos valores de amonio, fosfatos y materia orgánica. Por el contrario, las playas arenosas localizadas a $15 \mathrm{~km}$ de la ciudad fueron consideradas como "zonas no perturbadas" debido a que dominaron Psammodrilidae y Puelche orensanzi, con altos valores de nitratos y oxígeno disuelto. Estos taxa podrían ser buenos candidatos como indicadores de zonas limpias para futuros estudios. Se registra por primera vez la familia Psammodrilidae en el Atlántico Sur.
\end{abstract}

Palabras clave: Polychaeta, influencia antropogénica, comunidad macrobentónica, Capitella "capitata” sp., Boccardia polybranchia, Psammodrilidae, playas arenosas.

\section{INTRODUCTION}

The city of Puerto Madryn, on the Golfo Nuevo (south of Península de Valdés, northern Patagonia), has shown a rapid population increase since the 70s (6183 inhabitants during 1970 and 57614 during 2001; INDEC, 2001). The development of the region has generated environmental pressure on the coastal zone, with decreasing water quality (Esteves et al., 1997), toxic phytoplankton blooms (Esteves et 
al., 1992), and increasing kelp debris on the beaches (Eyras et al., 1999). Gil (2001) pointed out that part of these effects could be attributed to industrial effluents from fishery factories as potential sources of organic enrichment. Nevertheless, in some cases, the distinction between changes produced by natural factors, and those produced by anthropogenic activities is not clear (Warwick and Clarke, 1993).

Even when the pollution could be measured from the water column or the sediments (i.e. organic matter, dissolved oxygen, nutrients), these measures cannot clearly identify the impact on the ecosystem. Studies on the biological compartments are needed to assess the environmental impact. Benthic studies, and particularly those related to macrobenthos, are the most useful tool in environmental impact assessment. The effects produced by polluted water or sediments on the environment are determined better through the study of benthic communities than analyses of chemical features only (chemical concentrations higher than background references) (Chapman, 2007).

Polychaetes are one of the most useful organisms in impact studies. The dominance of some species belonging to the families Spionidae and Capitellidae is an indicator of organic pollution (i.e. Tsutsumi, 1990). Polychaetes have been used in bioassays for monitoring toxic compounds and as indicators of perturbed environments at the community, population and specific levels.

Few studies have been carried out on the macrofauna on soft bottoms around Península de Valdés. The only record for the intertidal zone of Golfo Nuevo is an unpublished study carried out at a station located in Puerto Madryn, which comprises macrofaunal aspects, such as biogeography and distribution patterns according to trophic guilds (Escofet, 1983). The relationships with environmental variables were not studied. Other unpublished studies have been performed in the infralittoral zone of the Golfo Nuevo (Carriquiriborde et al., 1983; Varela, 1985), and in the infralittoral and intertidal zones of the Golfo San Matías, located in the north of Península de Valdés (Escofet et al., 1978); however, only the names of dominant polychaete species were provided (Pastor de Ward, 2000). Recently, Pastor de Ward established polychaete assemblages based on abiotic and biotic factors through depth gradients (0 to $185 \mathrm{~m}$ depth). This study was performed in the Golfo San José, located in the north of the Península de Valdés (to the south of the Golfo San Matías), which is a wildlife reserve. None of these studies have focused on environmental impact assessment.

In order to assess the usefulness of the macrobenthic community (polychaetes in particular) in zones subjected to organic enrichment, a study at two tidal levels at 5 sites on sandy beaches around Puerto Madryn city was performed. The macrobenthic $(>0.5 \mathrm{~mm})$ community structure and environmental variables were measured in order to characterize zones subjected to different perturbation sources.

\section{MATERIALS AND METHODS}

The study area is located in the occidental part of the Golfo Nuevo, between $42^{\circ} 0.63^{\prime}$ and $42^{\circ} 0.76^{\prime} \mathrm{S}$ and $64^{\circ} 0.01^{\prime}$ and $64^{\circ} 0.98^{\prime} \mathrm{W}$ (Fig. 1). The semidiurnal tides of $4 \mathrm{~m}$ amplitude expose wide sandy intertidal areas, which are sheltered, and have a low wave intensity and slight slope (Monti and Bayarsky, 1996). The water temperature ranges from 10 to $17^{\circ} \mathrm{C}$ (De Vido and Esteves, 1978). Rain is scarce, with mean annual precipitations of $170 \mathrm{~mm}$ (Coronato and Vallejo, 1994).

During November 2005 five sites were sampled, one of them on a beach affected by the effluents of fish factories (Pesqueras), two on a beach affected by pluvial effluents and subsurface tap water (Moreno and 28 de julio), and two clean sites (Doradillo 1 and 2), which are located on a beach $15 \mathrm{~km}$ from the city (Fig. 1). At each level (low and mid tide), 5 cores of $10 \mathrm{~cm}$ in diameter and $12 \mathrm{~cm}$ depth $(78.5$ $\mathrm{cm}^{2}$ ) were randomly taken in the intertidal zone. One sediment aliquot for each replicate was taken and mixed to conform a single composed sample to determine granulometry, density, porosity and organic matter. The sediments were dried at $80^{\circ} \mathrm{C}$ until constant weight to determine porosity, while the organic matter content was measured in dry sediments by weight loss at $450^{\circ} \mathrm{C}$ during 4 hours (Billen, 1978). Dried sediments were sieved to obtain percentages of gravel $(>2 \mathrm{~mm})$, sand $(<2 \mathrm{~mm}$ and $>0.63 \mathrm{~mm})$ and mud $(<0.63 \mathrm{~mm})$ according to Folk (1968).

Salinity, temperature, dissolved oxygen, $\mathrm{pH}$, redox potential discontinuity, ammonium, nitrite, nitrate and phosphate concentrations were measured in the interstitial water. The $\mathrm{pH}$ and redox potential discontinuity were determined using Altronix TPA-1 equipment. Salinity was determined with a Plessey-6230N salinometer. Dissolved oxygen and temperature were measured using an YSI model 58 


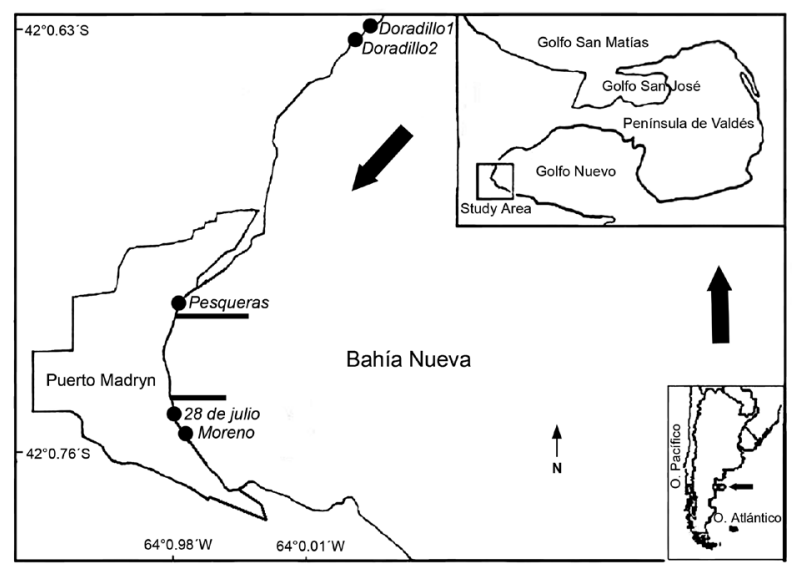

FIG. 1. - Study area showing the collection sites.

oxymeter. Ammonium, nitrite, nitrate and phosphate concentrations in the interstitial water of the lower intertidal level were determined in duplicate following the spectrophotometric techniques described by Strickland and Parsons (1972).

The biological samples were sieved through a 0.5 $\mathrm{mm}$ mesh and fixed in a neutral solution of formaldehyde (5\%). The specimens were preserved in $70 \%$ ethanol for further identification and counting.

Data analyses were performed using the software package PRIMER (Plymouth Marine Laboratory, UK). Species richness (S), abundance (A), the Shannon diversity index $\left(\mathrm{H}^{\prime}\right)$, and Pielou's equitativity index $\left(\mathrm{J}^{\prime}\right)$ were calculated for each collection site. Differences in each biological variable were evaluated through a two-way ANOVA with levels and collection sites as fixed factors $(n=50)$ (Statistica, version 7). The ordination was carried out with non-metric multidimensional scaling (nMDS) and the Bray-Curtis similarity index, using abundance transformed to the fourth root, which downweights the effect of rare and abundant species, to obtain the minimum stress (Field et al., 1982).

The differences among collection sites due to the presence of benthic organisms were evaluated with a one-way analysis of similarities (ANOSIM), while the analysis of similarity percentage (SIMPER) was used to determine the organisms that contributed most to the differences observed. Abundance data were used throughout. The relationships among the studied environmental variables and macrobenthos abundance were analyzed with an analysis of redundancy (RDA). The dimension of the factors was reduced using the subroutine Biplot of the Excel worksheet. The RDA represented the variables that best explained the high percentage of variation, while the variables that explained redundant information were eliminated (Jongman et al., 1995). Due to the absence of interstitial water at some collection sites of the middle intertidal level, the environmental variables could not be measured. Therefore, in order to compare the sites, only the environmental and biological variables from the lower intertidal level were taken into account for the RDA (since this analysis requires one environmental value for each biological value).

\section{RESULTS}

\section{Biological variables}

A total of 5317 organisms were counted and identified (Table 1), $90.78 \%$ of which were polychaetes, and the rest were oligochaetes, amphipods, copepods, tanaidaceans, insects and nemerteans.

The species richness showed highly significant differences between levels $(\mathrm{p}<0.002)$, and was higher at the lower level than at the middle one at all the collection sites (Fig. 2B). The mean abundance, equitativity and diversity did not show significant differences between levels. However, significant differences were detected among collection sites in species richness $(\mathrm{p}<0.000)$, abundance $(\mathrm{p}<0.024)$ and diversity $(\mathrm{p}<0.000)$, while equitativity did not show significant differences. Abundance was greater at the lower level from Pesqueras (Fig. 2A) and lower at both levels from Moreno (Table 1). Species richness and diversity were higher at both levels from 28 de julio (Fig. 2B and 2C). Finally, an interaction effect was registered (collection sites by level) in abundance $(\mathrm{p}<0.036)$.

The nMDS showed a good representation (stress= 0.08 ) and grouped Pesqueras with 28 de julio and the unperturbed sites (Doradillo 1 and 2), which were located on the opposite side of the diagram. Moreno was in an intermediate position (Fig. 3).

ANOSIM results showed highly significant differences between the two levels $(\mathrm{R}=0.319, \mathrm{p}<0.2 \%)$ and between sites $(\mathrm{R}=0.46, \mathrm{p}<0.1 \%)$. Differences between pairs of sites are shown in Table 2. Highly significant differences were found between Pesqueras and the rest of the sites as well as between Doradillo 2 compared with 28 de julio and Moreno.

The SIMPER analysis showed that the collection sites were dominated by different species: Boccardia polybranchia and Capitella "capitata" sp. at Pesqueras; Capitella "capitata” sp., Oligo- 
TABLE 1. - Total abundance (number of individuals) of species (5 replicates) by levels and collection sites (M: middle level; L: lower level).

\begin{tabular}{|c|c|c|c|c|c|c|c|c|c|c|}
\hline \multirow[t]{2}{*}{ Species } & \multicolumn{2}{|c|}{ Pesqueras } & \multicolumn{2}{|c|}{28 de julio } & \multicolumn{2}{|c|}{ Moreno } & \multicolumn{2}{|c|}{ Doradillo 1} & \multicolumn{2}{|c|}{ Doradillo 2} \\
\hline & M & $\mathrm{L}$ & M & $\mathrm{L}$ & $\mathrm{M}$ & $\mathrm{L}$ & $\mathrm{M}$ & $\mathrm{L}$ & & $\mathrm{L}$ \\
\hline \multicolumn{11}{|l|}{ Polychaeta } \\
\hline $\begin{array}{l}\text { Boccardia polybranchia } \\
\text { Spio quadrisetosa }\end{array}$ & 192 & 3538 & 39 & 26 & 1 & & & & & \\
\hline $\begin{array}{l}\text { Splo quatisetosa } \\
\text { Scoloplos sp. }\end{array}$ & 4 & 46 & 7 & $\begin{array}{c}8 \\
18\end{array}$ & & 1 & & & & \\
\hline Capitella "capitata" sp. & 20 & 73 & 306 & 36 & & & & & & \\
\hline Caulleriella sp.1 & 6 & 24 & & & & & & & & \\
\hline Paraonides sp.1 & & 1 & 57 & 123 & 5 & 6 & 2 & 3 & 4 & \\
\hline Syllidae indeterminated & & & 4 & 9 & 1 & 1 & & & & \\
\hline Exogone sp.1 & & & 2 & 6 & & & & & & \\
\hline Axiothella sp.1 & & & 6 & 95 & & & & & & \\
\hline Nereidae indeterminated & & & 1 & 1 & & & & & & \\
\hline Onuphis eremita & & & & 1 & & & & & & \\
\hline Travisia amadoi & & & & & & 1 & & 1 & & 2 \\
\hline Glycera sp. & & & & 1 & & & & & & \\
\hline Psammodrilidae indeterminated & & & & & & & & 55 & 3 & 91 \\
\hline Oligochaeta & & & & & & & & & & \\
\hline Oligochaeta sp.1 & & & 228 & 9 & & & & & & \\
\hline \multicolumn{11}{|l|}{ Amphipoda } \\
\hline Puelche orensanzi & & & & & & & 1 & 80 & & 93 \\
\hline Microphoxus cornutus & 1 & & 3 & 33 & & 1 & & & & \\
\hline Monoculopsis valentini & & & & 2 & & & & 1 & & \\
\hline Corophiidae indeterminated & 2 & & & & & & & & & \\
\hline \multicolumn{11}{|l|}{ Calanoidea } \\
\hline Calanoidea indeterminated & & & & 5 & & & & & & \\
\hline Tanaidacea & & & & & & & & & & \\
\hline Tanaidacea indeterminated & & 10 & & & & & & & & \\
\hline \multicolumn{11}{|l|}{ Crustacea } \\
\hline Crustacea indeterminated & & & & 1 & & & & & & \\
\hline \multicolumn{11}{|l|}{ Insecta } \\
\hline Insecta indeterminated & & & & & & & & 1 & 2 & 3 \\
\hline Nemertea & & & & & & & & & & \\
\hline Nemertea indeterminated & & & 5 & 1 & 2 & 6 & & & & \\
\hline
\end{tabular}
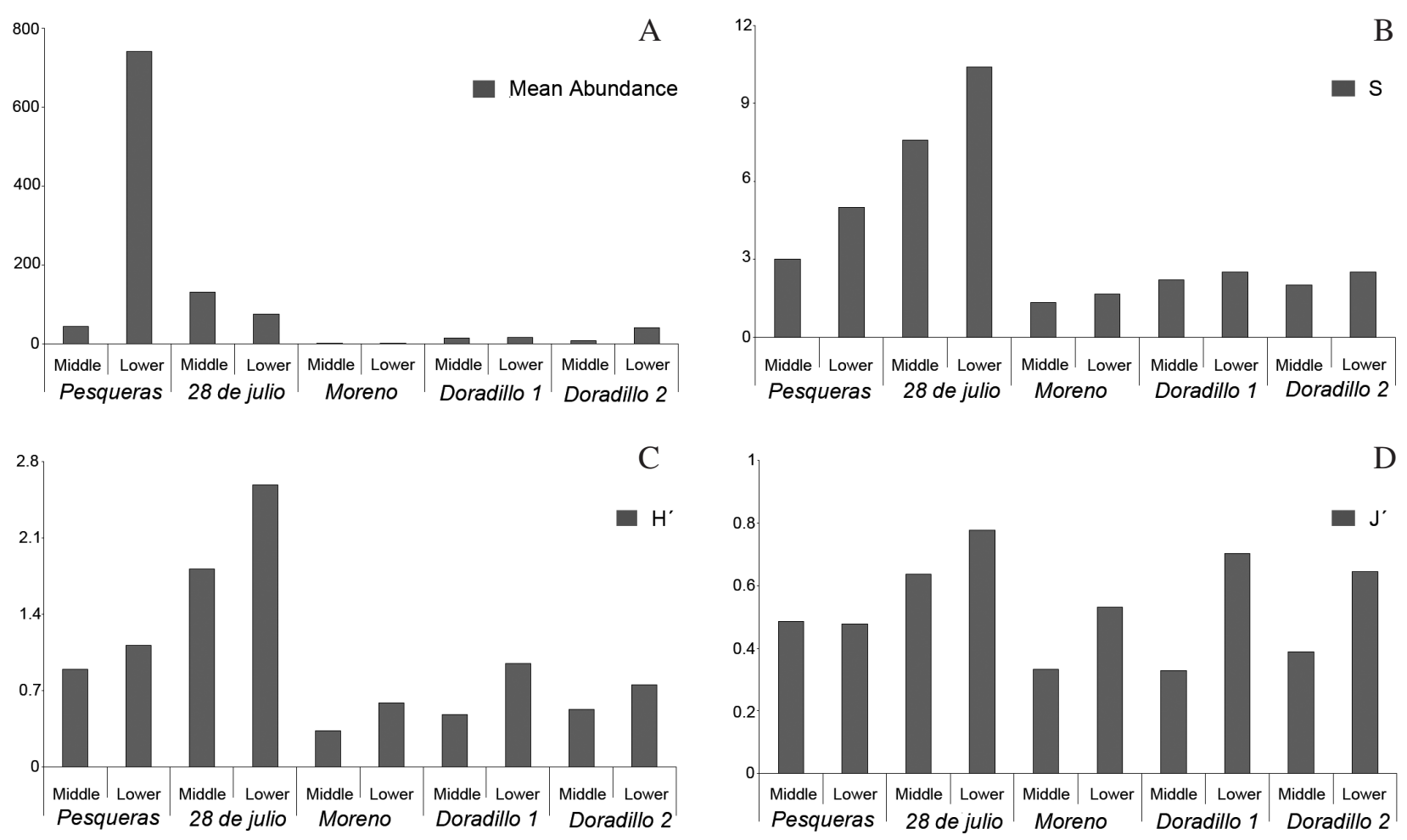

FIG. 2. - Biological variables at the middle and lower levels of the collection sites: A, mean abundance; B, species richness; C, Shannon diversity index and $\mathrm{D}$; equitativity. 


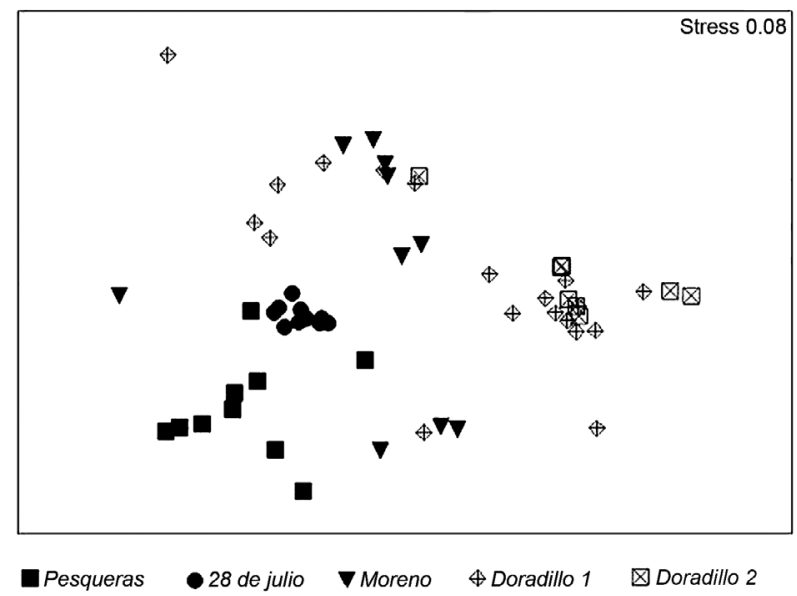

FIG. 3. - Multidimensional scaling diagram (nMDS) for the collection sites on sandy intertidal beaches of Puerto Madryn.

TABLE 2. - R-statistic values and significance levels (between brackets) in pairwaise comparisons among sites using the ANOSIM test. Significant differences in bold characters.

\begin{tabular}{lcccc}
\hline & 28 de julio & Moreno & Doradillo 1 & Doradillo 2 \\
\hline $\begin{array}{l}\text { Pesqueras } \\
\text { 28 de julio }\end{array}$ & $\mathbf{0 . 8 3 6 ( \mathbf { 0 . 1 } )}$ & $\mathbf{0 . 5 0 4}(\mathbf{0 . 2})$ & $\mathbf{0 . 5 7}(\mathbf{0 . 1})$ & $\mathbf{0 . 9 3 8}(\mathbf{0 . 1})$ \\
Moreno & $0.348(0.7)$ & $0.444(0.2)$ & $\mathbf{0 . 9 2 2}(\mathbf{0 . 1})$ \\
Doradillo 1 & & & $0.388(0.1)$ & $\mathbf{0 . 5 4 5}(\mathbf{0 . 1})$ \\
& & & $0.018(40.3)$ \\
\hline
\end{tabular}

chaeta sp. 1, Paraonides sp., Axiothella sp. and $B$. polybranchia at 28 de julio; and Psammodrilidae and Puelche orensanzi at Doradillo 1 and these two taxa with higher abundances at Doradillo 2. Moreno was characterized by Paraonides sp., with low mean abundance compared with the other sites (Table 1).

\section{Environmental variables}

Table 3 contains the results of the environmental variables measured at the lower level, which include water and sediment analyses. The collection sites showed a predominance of sandy sediments, except for Pesqueras, where the gravel fraction (pebbles) dominated. The organic matter contents were below $1 \%$ at all the sites. The lowest values were those from the two Doradillo sites $(0.5 \%)$ and the highest values were from 28 de julio $(0.9 \%)$. The dissolved oxygen showed high values, except at 28 de julio. The minimum redox potential discontinuity value was registered at Pesqueras $(-311 \mathrm{mV})$, which suggests that there are reduced chemical species such as hydrogen sulphide, methane and others at this site. The $\mathrm{pH}$ was almost neutral in all cases. The ammonium, nitrite and phosphate concentrations were highest at Pesqueras. The ammonium and nitrite concentrations were, respectively, one and two orders of magnitude higher than those from the other sites. Nitrate was higher at Doradillo 1 and Pesqueras $(9.0 \mu \mathrm{M}$ and 5.7 $\mu \mathrm{M}$ respectively). The phosphate concentration was higher at Pesqueras $(21.4 \mu \mathrm{M})$ than at the rest of the sites, while the lowest concentration was found at Doradillo $1(4.7 \mu \mathrm{M})$.

\section{Relationship between biological and environmental variables}

Axis I of the RDA performed with the environmental and biological variables from the lower level (Fig. 4) explained $70 \%$ of the variance and axis II explained $21.26 \%$, from a total variance of $91.26 \%$. Temperature, $\mathrm{pH}, \mathrm{Eh}$, salinity, percentage of gravel, density, porosity, and nitrite concentration, as well as 15 species were eliminated during the analysis because they explained redundant information. A high concentration of ammonium and phosphate were associated with Pesqueras, where B. poly-

TABLE 3. - Environmental variable values in the lower level.

\begin{tabular}{|c|c|c|c|c|c|}
\hline & Pesqueras & 28 de julio & Moreno & Doradillo 1 & Doradillo 2 \\
\hline Dissolved Oxygen (\%) & 40 & 29.3 & 37.6 & 67 & 39 \\
\hline Temperature $\left({ }^{\circ} \mathrm{C}\right)$ & 20.4 & 19.2 & 18.5 & 17 & 16.8 \\
\hline $\mathrm{pH}$ & 7.5 & 7.6 & 7.2 & 7.5 & 7.5 \\
\hline $\mathrm{Eh}(\mathrm{mV})$ & -311 & -38 & -54 & -25 & -34 \\
\hline Salinity & 35.13 & 34.06 & 32.33 & 36.60 & 29.63 \\
\hline Gravel (\%) & 61.4 & 2.4 & 7.6 & 2.1 & 2.4 \\
\hline Sand $(\%)$ & 38.5 & 95 & 92 & 97.7 & 97.4 \\
\hline Mud $(\%)$ & 0.1 & 2.6 & 0.4 & 0.2 & 0.2 \\
\hline Organic matter (\%) & 0.7 & 0.9 & 0.7 & 0.5 & 0.5 \\
\hline Density $\left(\mathrm{g} / \mathrm{cm}^{3}\right)$ & 2.0 & 1.7 & 1.8 & 2.0 & 1.7 \\
\hline Porosity $(\%)$ & 18 & 28 & 24 & 20 & 19 \\
\hline Ammonium $(\mu \mathrm{M})$ & 225.2 & 30.2 & 23.4 & 34.2 & 54.4 \\
\hline Nitrite $(\mu \mathrm{M})$ & 18.6 & 0.06 & 0.03 & 0.07 & 0.03 \\
\hline Nitrate $(\mu \mathrm{M})$ & 5.7 & 0.06 & 3.35 & 9.0 & 1.63 \\
\hline Phosphate $(\mu \mathrm{M})$ & 21.4 & 14.0 & 13.4 & 4.7 & 12.9 \\
\hline
\end{tabular}




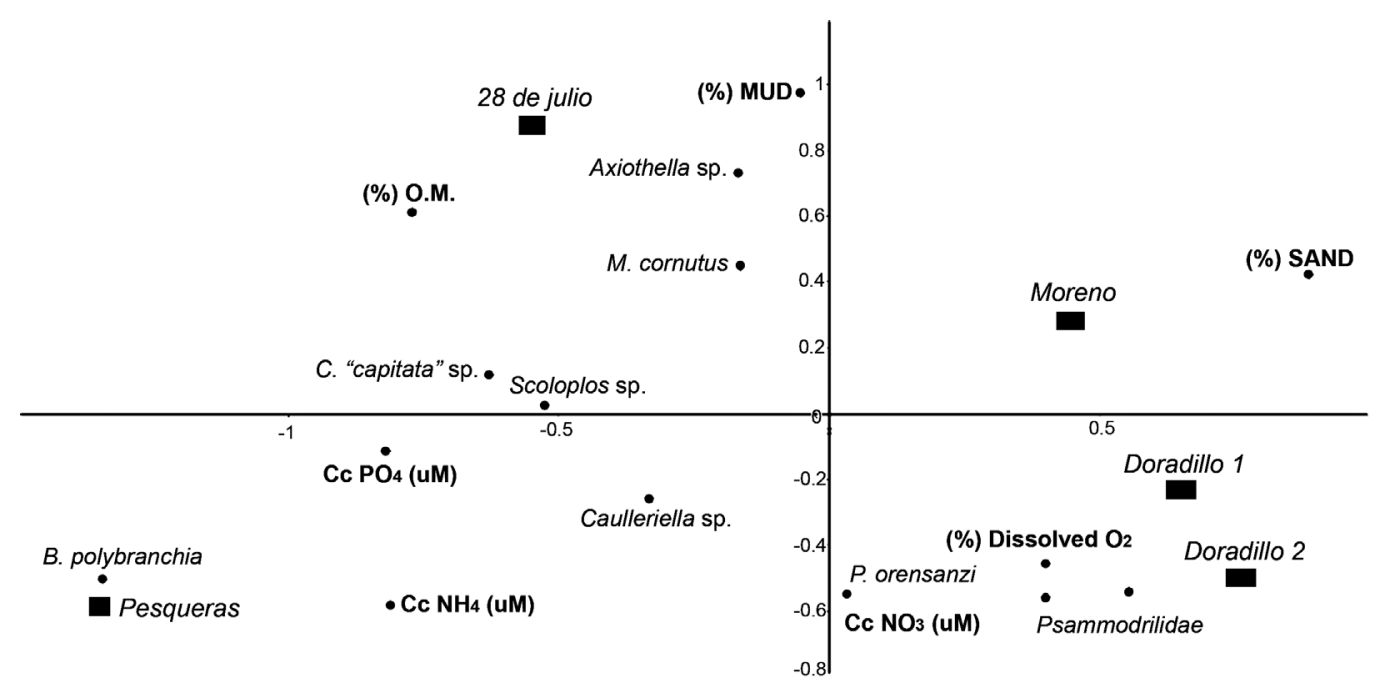

FIG. 4. - Redundancy analysis (RDA) showing collection sites, the main environmental variables and species.

branchia dominated. The site 28 de julio had high values of organic matter and mud, and Axiothella sp. was closely associated with it. C. "capitata" $\mathrm{sp}$. was located in an intermediate position between these two sites. High values of nitrate and dissolved oxygen were associated with Doradillo beach, with the dominance of Psammodrillid polychaetes and the amphipod $P$. orensanzi. Moreno was associated with sand and there were no dominant species.

\section{DISCUSSION}

This is the first record of the polychaete family Psammodrilidae Swedmark, 1952 in the South Atlantic. Up to date, five species of this family have been recognized in the North Atlantic and in New Zealand waters, from intertidal to subtidal depths (0-17 m), in clean fine to coarse sand (Worsaae and Sterrer, 2006).

Polychaetes represented the most important taxon of the present study, since they made up $58.33 \%$ of the species number and $90.78 \%$ of the abundance. Twenty-five years before our study, Escofet (1983) found that this group of organisms represented $70 \%$ and $80 \%$ of the species number and abundance respectively from the intertidal community of a Puerto Madryn beach (the 28 de julio site from this study). These percentages are in the same order of magnitude as our data despite the time elapsed between the two sampling periods and the expansive urban development in Puerto Madryn city since the 70s (Esteves et al., 1992; Esteves et al., 1997; Eyras et al., 1999; Gil, 2001). However, polychaetes found in this study are different from those recorded by Pastor de Ward (2000) in the Golfo San José, probably due to the geographic barrier (Fig. 1) and because this zone is not affected by anthropogenic disturbance.

The results from this study suggest that the area has different degrees of pollution based on the analyzed environmental and biological variables. Pesqueras showed the highest gravel content (almost $62 \%$ ) compared with the other collection sites, and had the lowest redox potential value $(-311 \mathrm{mV})$, which indicates the presence of chemical reduced species (Fenchel, 1969). Data analyses indicate that this site is associated with biological and environmental parameters related to pollution, like the dominance of $B$. polybranchia and C. "capitata" sp., and high amounts of ammonium and phosphate. This nutrient enrichment can be attributed to the effluents coming from the fishery factory, whose treatment plants do not always function efficiently. Although considerable amounts of organic matter coming from fishery activities are discharged into the environment, at this site the percentage was low $(0.7 \%)$ due to the coarse nature of the sediments that do not adsorb organic matter.

However, the 28 de julio site showed the highest diversity as it had the highest species richness, and redox potential discontinuity values as well as the highest organic matter content $(0.9 \%)$ and percentage of mud $(2.6 \%)$. This enrichment process was probably the result of a subsurface tap water filtration coming from the black wells and pluvial pipes without any maintenance. These results are similar to those found by Gil (2001), who observed that residual water of Puerto Madryn city could have an 
effect on the marine ecosystem. The characteristic species of this site were the detritivorous polychaetes Axiothella sp. and C. "capitata" sp.

The co-dominance of $B$. polybranchia and $C$. "capitata" sp., as well as the low percentages of organic matter in coarse sediments from Pesqueras and 28 de julio suggest that pollution is not severe enough to consider these areas as "very polluted zones", such as sites with highly organically enriched sediments reported by Reish (1959) in Los Angeles, Bellan (1967a,b) in Marseille, Pearson and Rosenberg (1978) in Loch Eil and Loch Linnhe, Cardell (1996) and Méndez et al. (1998) in Barcelona, and Rivero et al. (2005) in the Mar del Plata harbour. Therefore, these sites could be defined as "perturbed zones", which are equivalent to the "semi-healthy bottoms" or "polluted zones" as classified by Reish (1959) and Bellan (1967a, b) respectively.

The two sites located at Doradillo beach could be considered as "unperturbed zones" like the "healthy bottoms" of Reish (1959) and the "normal zones" of Bellan (1967a, b), due to the high values of dissolved oxygen and nitrates and low values of organic matter, which are not related to polluted conditions. The characteristic species at these two sites were psammodrilid polychaetes and the amphipod $P$. orensanzi, while the pollution indicator species were absent. This beach is located $15 \mathrm{~km}$ from the city and no anthropogenic activities are carried out in or around this zone, which explains the results found here.

The nMDS diagram obtained for the Moreno site shows that it is located in an intermediate position between the perturbed and unperturbed zones, while the RDA (including the environmental variables) indicates that this site is near the Doradillo sites. Although the Moreno and 28 de julio sites are close to pluvial effluents, the differences observed at the two locations may be due to the effect produced by the enriched subsurface tap water filtration in 28 de julio. Nevertheless, one or more variables that were not measured during the study were probably the main reason for the scarcity of macrobenthos recorded at the Moreno site, which could not be characterized based on our results.

Gray and Mirza (1979) pointed out that systems subjected to organic pollution are characterized by the dominance of only a few species. Thus, dominance is a good tool for defining indicator species of different degrees of organic pollution or unperturbed sites in specific areas. The indicator character of $B$. polybranchia and C. "capitata" sp. in the perturbed zones was confirmed here. These species have life history patterns that allow their rapid proliferation in available areas (Blake and Ruff, 2007). B. polybranchia is widespread in the Southern Hemisphere (Blake, 1983). It was found to be an indicator of intermediate organic pollution in association with an infaunal substrate created by intertidal mussel beds around sewage effluents of Mar del Plata (Elías et al., 2003, 2006). Similarly, the C. "capitata" species-complex has been considered as a universal pollution indicator when it proliferates in sediments containing high amounts of organic matter (Reish, 1959; Bellan, 1967a, b; Pearson and Rosenberg, 1978; Tsutsumi, 1990; Méndez et al., 1998).

The dominance of psammodrilid polychaetes and the amphipod $P$. orensanzi in unperturbed zones suggests that further studies over time are needed to determine whether these taxa are good indicators of clean sediments on Patagonian beaches. This proposal is supported by the fact that several studies performed in North Atlantic and New Zealand waters have found the family Psammodrilidae in clean sediments (Worsaae and Sterrer, 2006).

This study indicates the need for more continuity to better evaluate the health condition of the study zone over time. Thus, we recommend performing multidisciplinary studies using polychaetes to be able to assess the environmental impact produced by anthropogenic activities more easily. The first record of psammodrilids and their dominance observed here shows the importance of this family in the study area; therefore, further taxonomic, molecular and ecological studies should be performed.

\section{ACKNOWLEDGMENTS}

The authors are grateful to Andreana Cadaillón and Elvio Monteros for their assistance during field work, to Dr. José María Orensanz for his assistance in identification of polychaetes, to Lic. María Elena Gomez Simes for her help during amphipods identification. Lic. Mauricio Faleschini helped in processing samples. Thanks are also given to Dr. Inés Elías who allowed us to process the samples in her laboratory.

\section{REFERENCES}

Bellan, G. - 1967a. Pollution et peuplements benthiques sur substrat meuble dans la région de Marseille. Première Partie. Le Secteur de Cortiou. Rev. Int. Océanogr. Méd., VI-VII: 53-87. 
Bellan, G. - 1967b. Pollution et peuplements benthiques sur substrat meuble dans la région de Marseille. Deuxième Partie. L'ensemble portuaire marsellais. Rev. Int. Océanogr. Méd., VIII: $51-95$

Billen, G. - 1978. A budget of nitrogen recycling in North Sea sediments off the Belgian coast. Est. Coast. Mar. Sci., 7: 127-146.

Blake, J.A. - 1983. Polychaetes of the family Spionidae from South America, Antarctica and adjacent seas and islands. Biology of the Antarctic Seas XIV. Antarct. Res. Ser., 39(3): 205-288.

Blake, J.A. and E.R. Ruff. - 2007. Polychaeta. In: T.J. Carlton (ed.), Intertidal invertebrates from California to Oregon, pp. 309410. University of California Press. Los Angeles, California. University of California Press, Ltd. London, England.

Cardell, M.J. - 1996. Estructura y dinámica de la macrofauna bentónica en sedimentos marinos sometidos a vertidos domésticos e industriales: efecto de las aguas y lodos residuales de la planta depuradora de Sant Adrià del Besòs (Barcelonès). Ph. D. thesis Univ. Barcelona.

Carriquiriborde, L., C. Borzone, Z. Lizarralde, A. Pombo, R. Manriquez and M. Ichazo. - 1983. Aspectos biocenológicos del golfo Nuevo (Chubut, Argentina). Tech. Rep. Centro Nac. Patagónico, Puerto Madryn, Argentina.

Coronato, F. and M. Vallejo. - 1994. Atlas de la Provincia del Chubut. Saxon impresores S.R.L. Buenos Aires.

Chapman, P.M. - 2007. Determining when contamination is pollution- Weight of evidence determinations for sediments and effluents. Environ. Int., 33: 492-501.

De Vido, N.A. and J.L. Esteves. - 1978. Estudio preliminar de la variación estacional de parámetros físicos y químicos en el área de Bahía Nueva (Golfo Nuevo, Provincia del Chubut). Centro Nacional Patagónico (CONICET). Contribución No 26.

Elías, R., M.S. Rivero and E.A.Vallarino. - 2003. Sewage impact on the composition and distribution of polychaetes associated to intertidal mussel beds of the Mar del Plata rocky shore (Argentina). Iheringia, 93: 309-318.

Elías, R., M.S. Rivero, J.R Palacios and E.A. Vallarino. - 2006. Sewage-induced disturbance on polychaetes inhabiting intertidal mussel beds of Brachydontes rodriguezii off Mar del Plata (SW Atlantic, Argentina). In: R. Sardá, G. San Martín, E. López, D. Martín and D. Georg (eds.), Scientific Advances in Polychaete Research. Sci. Mar., 70S3: 187-196.

Escofet, A., J. M. Orensanz, S. R. Olivier and V. Scarabino. - 1978. Biocenología bentónica del golfo San Matías (Río Negro, Argentina): Metodología, experiencias y resultados del estudio ecológico de un gran espacio geográfico de América Latina. An. Inst. Cienc. del Mar Limnol., Univ. Nal. Autón. México, 5: 59-82.

Escofet, A. - 1983. Community ecology of sandy beach from Patagonia. MSc. thesis. Univ.Washington D.C.

Esteves, J.L., N. Santinelli, V. Sastre, R. Díaz and O. Rivas. -1992. A toxic dinoflagellate bloom and PSP production associated with upwelling in Golfo Nuevo, Patagonia Argentina, Argentina. Hidrobiología, 242: 115-122.

Esteves, J.L., M. Solís, M.N. Gil, N. Santinelli, V. Sastre, C. González-Raies, M. Hoffmeyer and M. Commendatore. - 1997. Evaluación de la contaminación urbana de la Bahía Nueva (Provincia del Chubut). Fundación Patagonia Natural.

Eyras, M.C., C.M. Rostagno and M.L. Piriz. - 1999. Algas marinas arribadas a la playa de Puerto Madryn: un indicador de cambios ambientales? Ficología International Symposium. Cultivation and use of red algae. V Congreso Latinoamericano. III Re- unión Iberoamericana. VII Simposio de algas marinas chilenas.

Fenchel, T. - 1969. The ecology of marine microbenthos. Structure and function of the benthic ecosystem, its chemical and physical factors and the microfauna communities with special reference of the ciliated protozoa. Ophelia, 6: 1-184.

Field, J.G., K.R. Clarke and R.M. Warwick. - 1982. A practical strategy for analysing multispecies distribution patterns. Mar. Ecol. Progr. Ser., 8: 37-52.

Folk, R.L. - 1968. Petrology of sedimentary rocks. Hemphills Publications Company, Austin.

Gil, M.N. - 2001. Eutroficación: rol del Nitrógeno en ecosistemas marinos costeros. Ph. D. thesis, Univ. Nacional del Sur, Buenos Aires.

Gray, J.S. and F.B. Mirza. - 1979. A possible method for the detection of pollution-induced disturbance on marine benthic communities. Mar. Poll. Bull., 10(5): 142-146.

INDEC. - 2001. Instituto Nacional de Estadísticas y Censo.[on line] Available by Internet: http://www.indec.gov.ar/

Jongman, R.H.G., C.J.F. Ter Braak and O.F.R. Van Tongeren. 1995. Data analysis in community and landscape ecology. Cambridge University Press, Cambridge.

Méndez, N., J. Flos and J. Romero. - 1998. Littoral soft-bottom Polychaete communities in a pollution gradient in front of Barcelona (Western Mediterranean, Spain). Bull. Mar. Sci., 63(1): 167-178.

Monti, A. and A. Bayarsky. - 1996. Tendencias generales del transporte de sedimentos de la playa de Puerto Madryn, Chubut. Acta VI Reun. Argentina Sedimentología.

Pastor de Ward, C.T. - 2000. Polychaete assemblages in the San José Gulf (Chubut, Argentina), in relation to abiotic and biotic factors. Mar. Ecol., 21: 1-16.

Pearson, T.H. and R. Rosenberg. - 1978. Macrobenthic succession in relation to organic enrichment and pollution of the marine environment. Oceanogr. Mar. Biol. Ann. Rev., 16: 229-311.

Poc Reish, D.J. - 1959. An ecological study of pollution in Los Angeles-Long Beach Harbours, California. Allan Hanckock Found. Publ., Occ. Pap., 22: 1-117.

Rivero, M.S., R. Elías and E.A. Vallarino. - 2005. First survey of macroinfauna in the Mar del Plata Harbour (Argentina), and the use of polychaetes as pollution indicators. Rev. Biol. Mar. Oceanogr., 40(2): 101-108.

Strickland, J.D.H. and T.R. Parsons. - 1972. A Practical Handbook of the seawater analysis. Fish. Res. Board Canadá, Otawa, Bull., 167.

Tsutsumi, H. - 1990. Population persistence of Capitella sp. (Polychaeta; Capitellidae) on a mud flat subject to environmental disturbance by organic enrichment. Mar. Ecol. Progr. Ser., 63: 147-156.

Varela, D. - 1985. Estudio cuali-cuantitativo de la macrofauna bentónica de la Bahía Nueva (Golfo Nuevo, Chubut). Thesis (First Degree), S. Natl. Univ. Bahía Blanca, Argentina.

Warwick, R.M. and K.R. Clarke. - 1993. Comparing the severity of disturbance: a meta-analysis of marine macrobenthic community data. Mar. Ecol. Prog. Ser., 92: 221-231.

Worsaae, K. and W. Sterrer. - 2006. Description of two new interstitial species of Psammodrilidae (Annelida) from Bermuda. Mar. Biol. Res., 2: 431-445.

Scient. ed.: R. Sardà.

Received September 1, 2009. Accepted October 6, 2009.

Published online March 19, 2010. 